\section{ВИЗНАЧЕННЯ ВПЛИВУ ЗМІН ОТОЧЕННЯ НА КОНКУРЕНТОСПРОМОЖНІСТЬ МОРСЬКИХ ПОРТІВ}

\author{
КАЛІНІНА Г. Г., \\ кандидат економічних наук, \\ доцент, Азовський морський \\ інститут Національного \\ університету «Одеська морська \\ академія» \\ КРАВЧЕНКО А. В., \\ кандидат економічних наук, \\ доцент
}

\section{DETERMINATION OF THE EFFECT OF CHANGE ON THE COMPETITIVENESS OF THE SEA PORTS}

\author{
KALININA H., \\ Candidate of Economic Sciences, \\ Associate Professor, Azov \\ Maritime Institute National \\ University "Odessa Maritime \\ Academy" \\ KRAVCHENKO A., \\ Candidate of Economic Sciences, \\ Associate Professor
}

У статті доведена необхідність дослідження чинників конкурентоспроможності портів. Підкреслена важливість урахування змін оточення морських портів. Наведено індикатори-драйвери конкурентоспроможності портів. Сформовано ієрархію основних рушійних факторів. Доведено, щзо великі галузеві трансформації здійснюють значний вплив на портову діяльність.

Ключові слова: конкурентоспроможність портів, чинники, індикатори, драйвери, зміни оточення, морські порти.

B статье доказана необходимость исследования факторов конкурентоспособности портов. Подчеркнута важность учета изменений окружения морских портов. Приведены индикаторы-драйверы конкурентоспособности портов. Сформирована иерархия основных движсущих факторов. Доказано, что крупные отраслевые трансформации осуществляют значительное влияние на портовую деятельность.

Ключевые слова: конкурентоспособность портов, факторы, индикаторы, драйверы, изменения окружения, морские порты.

The article proves the need to investigate the factors of competitiveness of ports. The importance of taking into account changes in the environment of seaports is emphasized. The indicators of drivers of port competitiveness are given. Form a hierarchy of major drivers. It has been proven that major sectoral transformations have a significant impact on port operations.

Key words: competitiveness of ports, factors, indicators, drivers, environmental changes, seaports.

Постановка проблеми. Дослідження науковців щодо конкурентоспроможності портів головним чином були зосереджені на визначенні рушійних чинників конкурентоспроможності портів та їх вимірюванні. У нашому дослідженні стверджується, що на ефективність діяльності порту, його конкурентоспроможність сильно впливають значні зміни в морській галузі, які 
вчені недостатньо вивчили. Отже, у центр уваги потрапила багатовимірність «конкурентоспроможності порту», яка розглядалась на основі опрацювання галузевих оглядів діяльності морських портів за період з 1983-2014 років. Аналіз дозволяє більш детально розглянути основні індикатори (драйвери) конкурентоспроможності портів та сформувати їх ієрархію.

Аналіз останніх досліджень $і$ публікацій. У літературі щодо стратегічного управління конкурентоспроможністю вивчається як порівняльна концепція щодо здатності забезпечити унікальну ціннісну пропозицію [1], [2] за кращих умов, ніж конкуренти [3]-[5]. Морська індустрія, яка складається 3 динамічних ділових мереж [6], розглядає конкурентоспроможність портів як функцію здатності всієї громади збільшувати ресурси, компетенції та можливості для загальної перспективи [7]. Дослідження теоретичних аспектів конкурентоспроможності портів було зосереджено на двох основних напрямках: встановлення індикаторів портової конкурентоспроможності [8], [9] та визначення впливу чинників конкурентоспроможності порту [9]. Отже, з теоретичної точки зору, необхідне створення загальної концептуальної основи для дослідження причиннонаслідкових зв'язків між різними підходами та повторної інтерпретації досліджуваних чинників у світлі основних галузевих тенденцій. Необхідно проаналізувати багатовимірність «портової конкурентоспроможності» шляхом визначення ієрархії основних індикаторів конкурентоспроможності шляхом розгляду галузевих оглядів діяльності морських портів за період з 1983-2014 років.

Метою статті є доведення необхідності дослідження впливу галузевих трансформацій на індикатори конкурентоспроможності сучасних морських портів.

Виклад основного матеріалу дослідження. Поняття конкурентоспроможності далеко не досягає однозначної концептуалізації, хоча воно широко обговорювалося в академічній літературі. В останні роки науковці відкрили плідні дискусії щодо низки нових галузей, що мають відповідні практичні наслідки для портів [10]. Зокрема, провідні вчені зосередили свої зусилля на вивченні деяких специфічних тенденцій, які, як стверджується, моделюють сучасний розвиток галузі: зростаюча економія масштабів у судноплавстві, інституційний поворот у портовому управлінні, зростання співдружності між портами в безпосередній близькості, розвиток міжфірмових мереж, а також тиск, який чинять проблеми, пов'язані із екологією та стійким станом розвитку [2]-[6]. Тому необхідно критично розглянути докази, спираючись на галузеві тенденції, визначені найбільш визнаними науковими роботами 3 морської логістики. Визначаючи та називаючи тематичні межі ключових галузевих тенденцій, було враховано різноманітність теоретичних аргументів. Ці галузеві тенденції забезпечують деякі інноваційні аналітичні аспекти, що сприяють конкурентоспроможності порту та спричиняють потенційні наслідки, спровоковані змінами у портовому та судноплавному секторах.

Економія масштабу в судноплавстві. Значне прискорення інвестицій провідних судновласників у судна $є$ першою передовою тенденцією, що спостерігається в галузі. Помітимо, що протягом останніх двадцяти років прагнення до економії масштабу, змусило переступити важливий розмірний поріг судна, в той же час наклало безпрецедентні операційні обмеження в портах. Як 
наслідок, порти та термінали були змушені робити великі та швидкі інвестиції в інфраструктуру, щоб впоратися 3 новими розмірами суден та зберегти конкурентоспроможність. Що стосується конкурентоспроможності портів, ця тенденція сильно впливає на відносини судно-порт, оскільки оперативні вузькі місця та неефективність портів неминуче $\epsilon$ наслідком недостатнього обгрунтування інфра- та надструктур. Порт, який не в змозі прийняти мега-судна, ризикує бути маргіналізованим у глибоководних схемах торгівлі. Незважаючи на те, що наявна література зазвичай приймає до уваги важливість таких факторів, як портові витрати, ефективність експлуатації та інфраструктурне благополуччя, вплив економії масштабу на конкурентоспроможність портів недостатньо досліджується. Дійсно, ця тенденція зробила сильний вплив на порти. Зростаюча кількість портів, ставила на меті забезпечення експлуатаційних показників за рахунок створенню спеціальних терміналів для судноплавних ліній, щоб забезпечити більш плавне переміщення вантажів з моря на сушу (Parola \& Musso, 2007). Створення таких об'єктів також забезпечує гарантію стабільної вантажної бази та представляс собою додатковий драйвер, здатний підвищити конкурентоспроможність порту в довгостроковій перспективі.

Крім того, поява мега-суден створює нові виклики функції синхронізації портів з точки зору операцій на суші [7]. Значне зростання розміру судна змусило порти досягти більш високого ступеня синхронізації із їхніми внутрішніми ділянками через спеціалізовані транспортні коридори великої місткості, що обслуговуються залізницею чи баржами, часто включаючи сухі порти. Висока доступність внутрішньої інфраструктури та ефективне сполучення, пристосоване до зростаючої спроможності суден, $€$ надзвичайним чинником, який може змінити конкурентну динаміку між портами, забезпечуючи більш високий рівень конкурентоспроможності. У зв'язку з цим ті портові органи, які здатні встановити ефективне державно-приватне партнерство та реалізувати далекоглядні стратегії внутрішнього розвитку та управління інфраструктурою, ймовірно, виграють в умовах конкурентної переваги та позиціонування на ринку [6].

Друга трансформація стосується глибокого інституційного повороту, який відбувся в галузі протягом останніх 20-30 років, як у країнах, що розвиваються, так і в розвинених економіках. Зокрема, перехід від державної до орендодавчої моделі у більшості країн дозволяс приватним фірмам долучитися до портових операцій та стимулює прийняття управлінських практик у реформованих портових органах [10]. Нові механізми управління в портових органах, включаючи гнучку та ефективну раду директорів (наприклад, невелика кількість виконавчих членів, деполітизацію правління тощо), дозволяють приймати швидкі виконавчі рішення, що відповідають потребам приватних фірм та забезпечувати швидкість підприємницьких дій [7]. Крім того, очікується, що створення інституційних ланцюгів, що характеризуються вертикальною координацією влади та компетенцій між різними державними органами (портові органи, муніципальна влада, центральні та місцеві уряди тощо), повинні посилити конкурентоспроможність порту. В цьому контексті, порт, адміністрація здатні активніше інвестувати у внутрішні проекти та більш ефективно організовувати транспортний ланцюг, використовуючи можливості "часових вікон". Наявність реформованого режиму управління дає змогу портовим властям взяти на себе зобов'язання щодо розширення стратегічних цілей та використання функцій та 
заходів, які звучать «інноваційно» 3 боку перспектив для державних установ. Наприклад маркетинг та комунікації, розвиток інформаційних технологій та управління відносинами 3 клієнтами [11]. Провідні портові органи виступають як "громадські" підприємці та активно займаються логістичними проектами за межами порту, щоб покращити товарні ланцюги поставок та власну конкурентоспроможність. 3 цього погляду розвиток проектів та інвестиції в закордонні країни повинні зміцнити свої позиції на ринку та збільшити потоки доходів.

Нарешті, реформа управління портами відкриє двері для приватних інвестицій та приватних діючих фірм, схильних до комерційного ризику. У зв'язку 3 цим наявність конкурентного ринкового середовища дозволяє менеджерам портових органів вибирати ефективних партнерів, які, в свою чергу, підсилюють конкурентоспроможність порту в цілому. Нажаль, сучасні науководослідні зусилля були зосереджені на причинах, що лежать в основі реформ управління портом, та на пов'язаних з цим інституційних, організаційних та стратегічних змінах, що відбуваються в ході цього процесу.

Співдружність між портами в безпосередній близькості. Третя хвиля змін створюється зростаючою взаємозалежністю між портами, розташованими в географічній близькості. Підвищена швидкість взаємозалежності спричинила змішане поєднання конкурентних стратегій та кооперативних стратегій. Поперше, поява парадигми «регіонального порту» означає новий етап розвитку портів, який характеризується поєднанням широких внутрішніх районів із сильною внутрішньопортовою конкуренцією. 3'являється спосіб впоратися 3 ключовими проблемами, пов'язаними з портами. Наприклад, перевантаженням, зростаючими витратами, обмеженою вантажопідйомністю, і в той же час мати можливість відповідати вимогам моделей розподілу вантажів [7]. Порти повинні зрозуміти, що конкурентоспроможність може бути обмежена їх фізичними потужностями, що стало критичним чинником їх успіху для зростання та виживання. Хоча суміжні порти, як правило, є сильними конкурентами за залучення споживачів та (іноземних) інвесторів, їх відносини також розвинулися в тому сенсі, що керівники портових органів та керівники приватних фірм шукають можливості для співпраці та координації в різних сферах [7], [8]. До причини, що обумовили такі зусилля портових властей щодо координації 3 сусідніми портами, можна віднести: раціоналізацію портових просторів та доступної транспортної інфраструктури, побудову нової інфраструктури для об'єднання фінансових ресурсів, створення «лобі» для отримання державних коштів, просування порту шляхом спільного маркетингу та комунікаційної діяльності, реалізацію маркетингових досліджень та спільних проектів із охорони навколишнього середовища, досліджень та розробок та питань безпеки. Зрештою, співпраця між портами, що знаходяться в безпосередній близькості, є головним засобом підвищення конкурентоспроможності, оскільки вона здатна пом'якшити (недобросовісну) конкуренцію між сусідніми портами та боротися 3 посиленням міжнародної конкуренції [7], [8].

Міжфірмові мережі. Четверта передова трансформація галузі представлена зростанням міжфірмових мереж у судноплавстві та портах. В принципі, зміцнення зв'язків кооперативів між приватними фірмами призвело до переходу парадигми переговорної влади з публічної на приватну. По-перше, розвиток консорціумів та 
глобальних альянсів у судноплавстві здійснив сильний тиск на порти. Для портових властей стає критично важливим працювати 3 великими альянсами судновласників, які ділять ємність судна та інвестиції, i таким чином демонструють зростаючі експлуатаційні потреби (наприклад, портові витрати, портова інфраструктура, якість портових послуг, експлуатаційна ефективність тощо). Наприклад, фідалізація клієнтів може передбачати присвоєння спеціалізованих портових потужностей або послуг таким групам судновласників. Втрата великого замовника та його партнерів може призвести до великого перенаправлення трафіку до конкуруючих портів i, як наслідок, значно знизити конкурентоспроможність портів у довгостроковій перспективі. У зв'язку з цим в науковій літературі слід додатково дослідити вплив, який здійснюють міжфірмові угоди між океанськими перевізниками на стратегії портових адміністрацій (наприклад, спеціальні термінали для консорціумів, спеціальні послуги для альянсів, тощо) і нарешті, на конкурентоспроможність порту.

Спільні зв'язки також поширилися серед фірм, що працюють у портових терміналах [11]. За останні десятиліття, власне, структурні зміни в портових операціях та власності, які супроводжуються зростанням багатонаціональних підприємств контейнерних портів, які переросли свої країни, які управляють широким портфелем об'єктів на корпоративних принципах. Прогресивна зрілість портового бізнесу стимулює портовий менеджмент застосовувати угоди про співпрацю 3 метою розширення їх географічного розмаху та розподілу інвестиційного ризику [11]. Встановлення складної архітектури добровільних зв'язків у портовій галузі призвело до зародження організаційних мереж, що сильно вплинуло на управління та планування в портах. У такій перспективі очікується, що об'єднання суттєво впливають на поведінку портових органів щодо планування та використання пунктів призначення портових районів. Корпоративний штаб формує стратегії діяльності місцевих терміналів, і може накласти сильний тиск на портові органи влади через свою переговорну силу. Потенційна зміна стратегічних рішень у порту у штаб-квартирах глобальних фірм може послабити виконавчу роль портової адміністрації та створити конфлікти через невідповідність місцевих державних інтересів та приватних стратегічних цілей. Крім того, ділокалізація виконавчої влади може викликати занепокоєння в діалектиці між інтересами місцевих підприємців та глобальних фірм, які, натомість, повинні співіснувати та знаходити посередництво у портовій сфері.

Виникнення екологічних проблем та питань, пов'язаних із стабільністю, $\epsilon$ передовими індикаторами змін у портовій та логістичній галузі. Незважаючи на те, що екологічні стратегії порту можуть виглядати лише як додаткова вигода для забезпечення ефективності чи необхідності дотримання вимог, вона все частіше стає основним стовпом у всій стратегічній траєкторії, враховуючи крихкий баланс між ефективністю, стійким зростанням показників на транспорті та логістикою. Дійсно, екологічна стійкість представляє зростаючу стурбованість портових органів, політиків, споживачів портів та місцевих громад. У зв'язку з цим технічні та технологічні інновації можуть забезпечити вирішення основних екологічних питань, зберегти стандарти якості та в кінцевому підсумку підвищити ефективність та конкурентоспроможність. Порт, який знаходиться на межі зелених технологій, завдяки своїм рішенням в морських та внутрішніх операціях може покращити свій імідж на ринку та залучити фірми, які поділяють зелену 
орієнтацію. Однак ми маємо визнати, що інновації часто зустрічають опір. Що стосується портів, екологічна стійкість потребує вдосконалених концептуальних рамок для інновацій. Більш конкретно, для ії впровадження та успіху необхідна тісніша взаємодія між державними та приватними суб'єктами. Як результат, академічна література покликана дослідити вплив на драйвери портової конкурентоспроможності, не лише вирішуючи роль зелених інновацій, але й висвітлюючи характер та якість відносин між учасниками спільної участі у розробці нових зелених рішень.

Довгострокові стратегії планування значною мірою залежать від конфліктних відносин між морським портом та територією, оскільки вона впливає на спроможність порту боротися із забрудненням води, повітря, а також заторами руху. Відповідні екологічні стратегії можуть сприяти побудові ефективних та плідних відносин місто-порт, що характеризуються соціальною стабільністю та консенсусом (тобто ефективним місцевим управлінням). Низький рівень схильності до конфліктів на навколишній території може в кінцевому підсумку підвищити конкурентоспроможність порту. Нарешті, незважаючи на примусовий характер багатьох екологічних правил, екологічні стратегії можуть надати сильну підтримку у збереженні іміджу порту та у створенні міцної репутації. В цілому концептуальний зв'язок між результатами екологічних стратегій та ліній конкурентоспроможності портів недостатньо обговорювався в літературі.

Висновки $і$ перспективи подальших досліджень. Незважаючи на те, що попередні дослідження визначили ряд відповідних факторів, що впливають на конкурентоспроможність портів, часто науковці не приділяли достатньої уваги детальним тлумаченням деяких змін у передових галузях, які сильно вплинули на конкурентоспроможність портів та їх рушійні чинники розвитку.

Тому було проаналізовано багатовимірність «портової конкурентоспроможності», щоб класифікувати основні індикатори конкурентоспроможності шляхом систематичного огляду галузевої літератури. 3 теоретичної точки зору дослідження розробляє підхід для реінтерпретації досліджуваних індикаторів у світлі основних галузевих тенденцій.

Основні висновки забезпечують ієрархію основних індикаторів та дозволяють припустити, що економія масштабів судноплавства, зміни в управлінні портами, співпраця між портами в спеціалізації, міжфірмових мереж, а також проблеми екологічного та стійкого розвитку, пом'якшують впливову роль традиційних індикаторів та перетворюють напрямки їх дії.

Вимірювання впливу змін в управлінні портами на конкурентоспроможність порту має бути надалі досліджено в майбутньому, враховуючи потенційний внесок реформ в портове управління для перестановки ієрархії драйверів конкурентоспроможності. Майбутні дослідження повинні поглибити концептуальні зв'язки між екологічними стратегіями та конкурентоспроможністю портів, підкреслюючи роль таких факторів, як стійкість до інновацій, репутація порту та соціальна та політична напруженість, які можуть принести новіуявлення про ієрархію індикаторівдрайверів конкурентоспроможності. 
Лimepamypa:

1. Prahalad C. K. \& Hamel G. The core competence of the corporation. Boston (Ma). 1990, pp.235-256.

2. Woodall T. Conceptualising 'value for the customer': an attributional, structural and dispositional analysis. Academy of Marketing Science Review. 2003. Vol.2(1), pp.1-42.

3. Porter M. E. Competitive strategy. New York: Free Press. 1980.

4. Grant R.M. The resource-based theory of competitive advantage: implications for strategy formulation. Knowledge and Strategy, 1991, pp.3-23.

5. Barney J. Firm resources and sustained competitive advantage. Journal of Management. 1991. Vol.7(1), pp. 99-120.

6. Van der Lugt L. M., De Langen P. W. \& Hagdorn L. Value capture and value creation in the ports 'business ecosystem'. Paper presented at the Annual Conference of the International association of Maritime Economists (IAME) 2007. July, Athens.

7. Nalebuff B. J., Brandenburger A., Maulana A. Coopetition, ISL Forlang AB Oskarshamn. 1996.

8. Pearson R. Containerline Performance and Service Quality. University of Liverpool. 1980.

9. Tongzon J. \& Heng W. Port privatization, efficiency and competitiveness: Some empirical evidence from container ports (terminals). Transportation Research Part A: Policy and Practice. 2005. Vol.59(5), pp.405-424.

10. Ng A. K., Ducruet C., Jacobs W., Monios J., Notteboom T., Rodrigue J. P., \& Wilmsmeier G. Port geography at the crossroads with human geography: between flows and spaces. Journal of Transport Geography. 2014. Vol. 41, pp. 84-96.

11. Parola F. \& Coppola, G. D. Critical issues in managing port security across EU: Evidence from Italy. International Journal of Transport Economics. 2011. Vol. $55(3)$.

\section{Referenses:}

1. Prahalad, C. K. \& Hamel, G. (1990). The core competence of the corporation. Boston (Ma), pp.235-256.

2. Woodall, T. (2003). Conceptualising 'value for the customer': an attributional, structural and dispositional analysis. Academy of Marketing Science Review, Vol.2(1), pp.1-42.

3. Porter, M.E. (1980) Competitive strategy. New York: Free Press.

4. Grant, R. M. (1991). The resource-based theory of competitive advantage: implications for strategy formulation. Knowledge and Strategy, pp. 3-23.

5. Barney, J. (1991). Firm resources and sustained competitive advantage. Journal of Management, Vol.7(1), pp.99-120.

6. Van der Lugt, L.M., De Langen P.W., \& Hagdorn, L. (2007). Value capture and value creation in the ports 'business ecosystem'. Paper presented at the Annual Conference of the International association of Maritime Economists (IAME), July, Athens.

7. Nalebuff, B.J., Brandenburger, A., \& Maulana, A. (1996). Coopetition, ISL Forlang AB Oskarshamn. 
8. Pearson, R. (1980). Containerline Performance and Service Quality. University of Liverpool.

9. Tongzon, J. \& Heng, W. (2005). Port privatization, efficiency and competitiveness: Some empirical evidence from container ports (terminals).Transportation Research Part A: Policy and Practice, Vol.59(5), pp. 405424.

10. Ng, A. K., Ducruet, C., Jacobs, W., Monios, J., Notteboom, T., Rodrigue, J. P., ... \& Wilmsmeier, G. (2014). Port geography at the crossroads with human geography: between flows and spaces. Journal of Transport Geography, Vol. 41, pp. 8496.

11. Parola, F. \& Coppola, G. D. (2011). Critical issues in managing port security across EU: Evidence from Italy. International Journal of Transport Economics, Vol. 55(3).

Research on port competitiveness has mainly focused on identifying the drivers of port competitiveness and measuring them. In our study, it is argued that the port's efficiency and competitiveness are strongly influenced by significant changes in the maritime industry that have been poorly understood by scientists. Therefore, the focus was on the multidimensionality of "port competitiveness", which was considered on the basis of the elaboration of sectoral reviews of the activities of seaports from 1983 to 2014. The analysis makes it possible to examine in more detail the main indicators (drivers) of the competitiveness of ports and to form their hierarchy.

The literature on strategic competitiveness management has been studied as a comparative concept on the ability to provide a unique value proposition under better conditions than competitors. The maritime industry, which consists of dynamic business networks, considers the competitiveness of ports as a function of the ability of the entire community to increase resources, competencies and opportunities for the overall perspective. The study of the theoretical aspects of port competitiveness has focused on two main areas: establishing indicators of port competitiveness and determining the impact of port competitiveness factors. Therefore, from a theoretical point of view, it is necessary to create a common conceptual framework for the study of cause and effect relationships between different approaches and the re-interpretation of the factors studied in the light of major industry trends. It is necessary to analyze the multidimensionality of "port competitiveness" by defining a hierarchy of major competitiveness indicators by reviewing sectoral reviews of seaports activity from 19832014.

Although previous studies have identified a number of relevant factors affecting port competitiveness, researchers have often not paid sufficient attention to detailing some of the changes in the advanced industries that have had a major impact on port competitiveness and their driving factors.

Therefore, the multidimensionality of "port competitiveness" was analyzed to classify major competitiveness indicators through a systematic review of industry literature. From a theoretical point of view, the study develops an approach for reinterpreting the studied indicators in the light of major industry trends.

The main findings provide a hierarchy of core indicators and suggest that economies of scale, changes in port management, cooperation between ports in 
specialization, inter-firm networks, and environmental and sustainable development problems mitigate the influential role of traditional indicators and transform their direction.

Measuring the impact of changes in port management on port competitiveness should be further explored in the future, taking into account the potential contribution of port management reforms to replacing the hierarchy of competitive drivers. Future research should deepen the conceptual link between environmental strategies and the competitiveness of ports, highlighting the role of factors such as innovation resilience, port reputation and social and political tensions that can bring new insights into the hierarchy of competitive driver indicators. 